\title{
REMOTE SENSING AND GIS BASED SITE SUITABILITY ANALYSIS FOR TOURISM DEVELOPMENT IN VAISHALI BLOCK, BIHAR, INDIA
}

\author{
J.RAJESH*1, B.SANTHOSH KUMAR ${ }^{2}$, SUDHIR KUMAR SINGH ${ }^{3}$ \\ ${ }^{1}$ Research Scientist, Mahatma Phule Krishi Vidyapeeth, Rahuri-413 722, Dist-Ahmed- \\ nagar, Maharashtra, India. \\ ${ }^{2}$ Junior Research Fellow, Department of Remote Sensing, Bharathidasan University, \\ Trichy, India. \\ ${ }^{3}$ Assistant Professor, K. Banerjee Centre of Atmospheric \& Ocean Studies, IIDS, Nehru \\ Science Centre, University of Allahabad,Prayagraj-211002, Uttar Pradesh, India \\ *Email: drjrajesh89@gmail.com
}

Received 3 May 2021, accepted in revised form 14 September2021

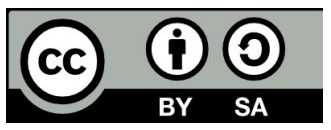

\begin{abstract}
Nowadays, GIS is widely recognized as a valuable decision support system that enables the determination of suitable spatial locations for a specific objective based on a group of criteria. This paper aims to utilize such a comprehensive approach for delineating suitable sites to set up future tourist infrastructures in vaishali block, Bihar, India. Several recent databases have been gathered, integrated, processed, and analyzed for the study area. Six criteria have been designed and applied for finding safe, homogenously-distrusted, and economical optimal locations for potential tourist facilities in the study area. A suitability map has been developed based on a weighted integration of the chosen six criteria. According to our present investigation; the most reasonable the travel industry site recognized by the examination is inside significant towns. The urban focus with plausibility to develop into the travel industry focuses. The rest of the land shows a low appropriateness scale because of absence of significant appreciation for make a solid force factor. Availability is an essential for the travel industry advancement. Great street organize availability with closeness to railroads station or air terminal demonstrated solid vacationer potential site, this combined with proximity to grand magnificence delineates high appropriateness. Significant vacation destinations, for example, legacy locales, gardens and water bodies or lake demonstrated high appropriateness. This can be corresponded to the way that legacy destinations and other high appropriate highlights are converted into reasonable the travel industry site.
\end{abstract}

Keywords: Site Suitability Analysis, Multi Criteria, Tourism Land use, Remote Sensing, GIS

\section{Introduction}

Geographic Information Systems (GIS) and the travel industry share a typical trademark, that is, both cross the limits of controls and application territories. GIS has been applied in numerous controls including geology, ranger service, urban arranging, and natural investigations. So also, the travel industry has been a subject of interests to geographers, financial specialists, business, natural organizers, anthropologists, and archeologists (Wayne Giles, 2003). Accordingly, the potential for GIS applications in the travel industry is critical. GIS is presently perceived broadly as a significant instrument for overseeing, breaking down, and showing 
enormous volumes of differing information appropriate to numerous neighborhood and territorial arranging exercises. Its utilization in natural arranging is quickly expanding (Bualhamam, 2009). The travel industry is a movement profoundly subject to natural assets. It is additionally a marvel, which in case of an absence of arranging and the board is probably going to dissolve its ecological base. Thus, the quality of the travel industry arranging can be upgraded by GIS applications. GIS can be viewed as giving a tool compartment of methods and advances of wide appropriateness to the accomplishment of economical the travel industry improvement.

This paper examined the capability of GIS applications in the travel industry. Specifically, it will feature the restrictions of the travel industry explicit GIS applications. So as to assess the worth and extent of GIS in the travel industry arranging and improvement, this paper will audit existing GIS applications which are appropriate in the travel industry arranging (Savigny, and Wijeyaratne, 1994); talk about some methodological constraints in applying GIS in the travel industry arranging; and distinguish some potential regions of utilizations in Vaishali block, Bihar.
Site appropriateness is a procedure which investigations the benefits of potential areas where a characterized use or action can be performed (Opadeyi, and Nizeyimana, 2005). Its motivation is to recognize the most fitting regions for a potential land use improvement movement, for example, mechanical advancement, the travel industry improvement, for example, horticultural land use, potential territories for ranger service, and other such land use exercises.

The procedure of site appropriateness requires the recognizable proof of the fitting areas for a specific land use movement by thinking about physical assets (Laurin, and Ongaro, 2006) (height, incline, perspective, atmosphere), common assets (soils, geography, hydrology, greenery living space, and ecologically delicate zones), and existing area use and improvement (artificial offices, for example, transportation frameworks, existing urban regions, and utility systems). These various sorts of data comprise the "criteria" in light of which the territory viable (Keeney, \& Raiffa, 1993). These criteria are exclusively considered to distinguish regions of chance (zones appropriate to the land use viable) and limitations (regions not reasonable to the land use viable). The main
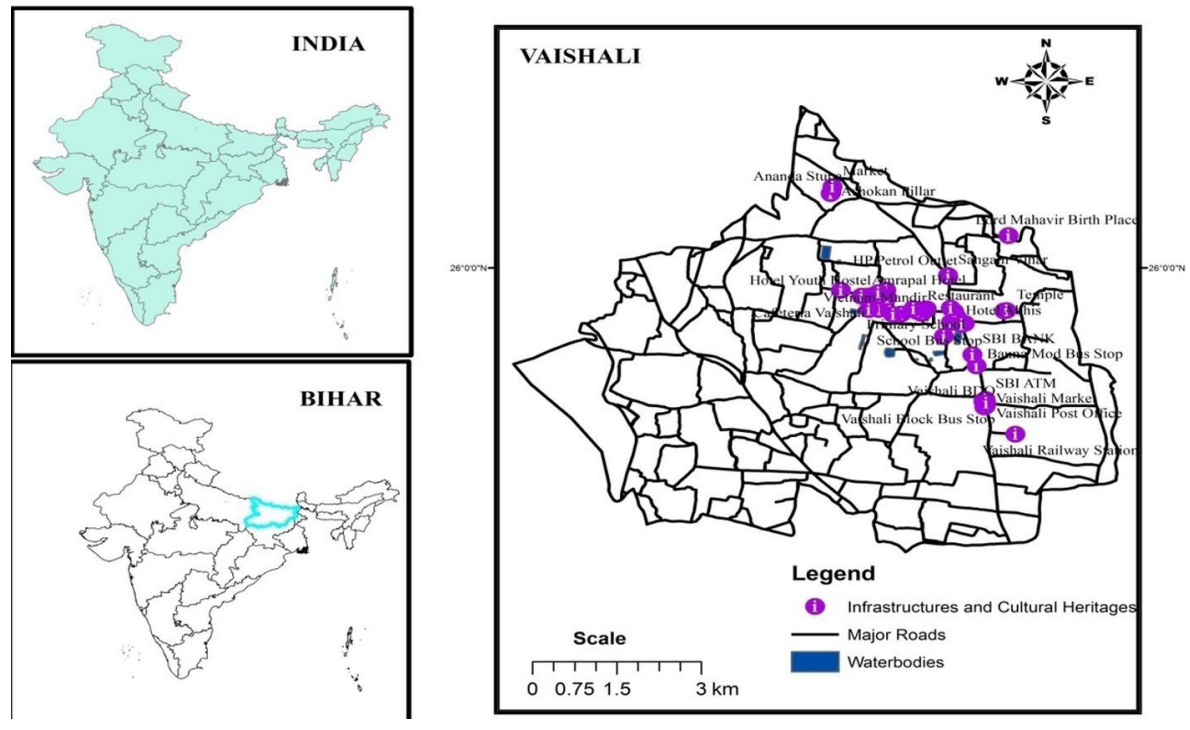

Fig.1 Study area 
objectives of the study area are: Protect and monitor social legacy and normal assets; Create new the travel industry opportunity; Promote ethnic assorted variety; and Facilitate impartial financial development (Zopounidis, and Doumpos, 2002).

\section{Study area}

The study area is spread over 49.71 sq. $\mathrm{km}$ zone and has a populace of 187406 . The study area is and is limited by Muzaffarpur (North), Patna (South), Samastipur (East) and Saran (West).Vaishali square encased 114 towns. The Hajipur town is encompassed by Narayani Gandak River in the west and sacred Ganga River in south. Unmistakable Mahatma Gandhi Setu over stream Ganga connects it with the state capital Patna; while extra rail and Road Bridge over Gandak goes along with it with Sonepur, headquarter of a railroad sub-division under ECR. The plain place where there is town and its bordering places is celebrated for banana, Litchi and mango manors. The district appearances green with plants and trees developing in semi-tropical storm atmosphere. In any case, long stretches of May-June are hot and December-January is cold (Fig.1).

\section{Methodology}

The idea for finding fitting locales for each land use action is guided by the plan to limit the conceivable unfriendly impacts of advancement on the earth and on existing networks, and to stress the positive effects of such improvement, by finding them in a most reasonable area (UN Guideline, 1999).This is accomplished by looking at various individual criteria, appointing them relative degrees of significance in general, and utilizing a numerical resultant model to recognize the most appropriate area. By embracing this site reasonableness technique, it is conceivable to methodicallly distinguish the criteria considered, obviously record the overall significance of one standard over another, investigate the net result utilizing a Geographic Information System, and afterward perhaps return to the scientific connections in this "decision model"(Salo, and Hamalainen, 1995). By modifying the relative significance to distinguished criteria dependent on the specific land use viable, it is conceivable to create "reasonableness maps" for every individual landuse, and afterward produce a last composite land utilize that depends on a most ideal aggregate appropriateness of different land employments.

To accomplish this, every one of the criteria are allocated a "position" signifying their general degrees of significance inside the reasonableness study. These positions are appointed as numeric qualities extending from 1 to 10 , with 1 mirroring a low degree of significance and 10 mirroring an elevated level of significance. For instance, inside the criteria of street systems, national expressways would impact the reasonableness for a specific land use, as contrasted and neighborhood streets. Further, the good ways from every one of these highlights would additionally change the overall appropriateness of a land utilize dependent on the vicinity to a specific sort of street. To suitably incorporate this geographic fluctuation over the local arranging degree, a comparative size of 1 to 10 is utilized to relegate singular "loads" in view of the proximal relationship to every specific component type inside a particular criteria utilized in the choice model (LigmannZielinska, and Jankowski, 2008). All things considered, the loads, duplicated by the position, give an appropriateness score that aggregately is utilized to recognize the most reasonable areas for the distinguished land use inside the provincial arranging space, which is shown as a "land reasonableness map". 
Table 1. Data Used and Sources

\begin{tabular}{|c|c|c|}
\hline S.No & $\begin{array}{l}\text { Input Data } \\
\text { Layers }\end{array}$ & Sources \\
\hline 1 & Base Map & Topographical Map @ 1:25,000 Scale \\
\hline 2 & Land Use Map & other Related Maps \\
\hline \multirow{3}{*}{3} & \multirow{3}{*}{$\begin{array}{l}\text { Topographical } \\
\text { Map }\end{array}$} & $\begin{array}{c}\text { LANDSAT - } 8 \text { OLI + Satellite Imagery } \\
\text { (30 m Spatial Resolution) }\end{array}$ \\
\hline & & Topographical Map @ 1:25,000 Scale \\
\hline & & $\begin{array}{l}\text { ASTER - DEM (30 m Spatial } \\
\text { Resolution) }\end{array}$ \\
\hline 4 & Soil Map & $\begin{array}{c}\text { National Bureau of Soil and Land use } \\
\text { Planning survey }\end{array}$ \\
\hline 5 & Geological Map & Geological Survey of India \\
\hline 6 & Hydrology & $\begin{array}{c}\text { LANDSAT - } 8 \text { OLI + Satellite Imagery } \\
\text { (30 m Spatial Resolution) }\end{array}$ \\
\hline \multirow[t]{2}{*}{7} & $\begin{array}{l}\text { Environmental } \\
\text { Sensitive Area }\end{array}$ & $\begin{array}{l}\text { LANDSAT - } 8 \text { OLI + Satellite Imagery } \\
\text { (30 m Spatial Resolution) }\end{array}$ \\
\hline & & Topographical Map @ 1:25,000 Scale \\
\hline
\end{tabular}

\section{Criteria for site analysis}

The choice criteria for site choice are watched for doling out relative positions and individual component loads dependent on the land use type for which wellness is being considered. For the benefit of examination, the criteria under worry in this paper movement are readied.

\section{GIS based site suitability analysis model}

We were developing a tourism site suitability analysis model in ArcGIS - 10.1, which is displayed in (Fig.2).

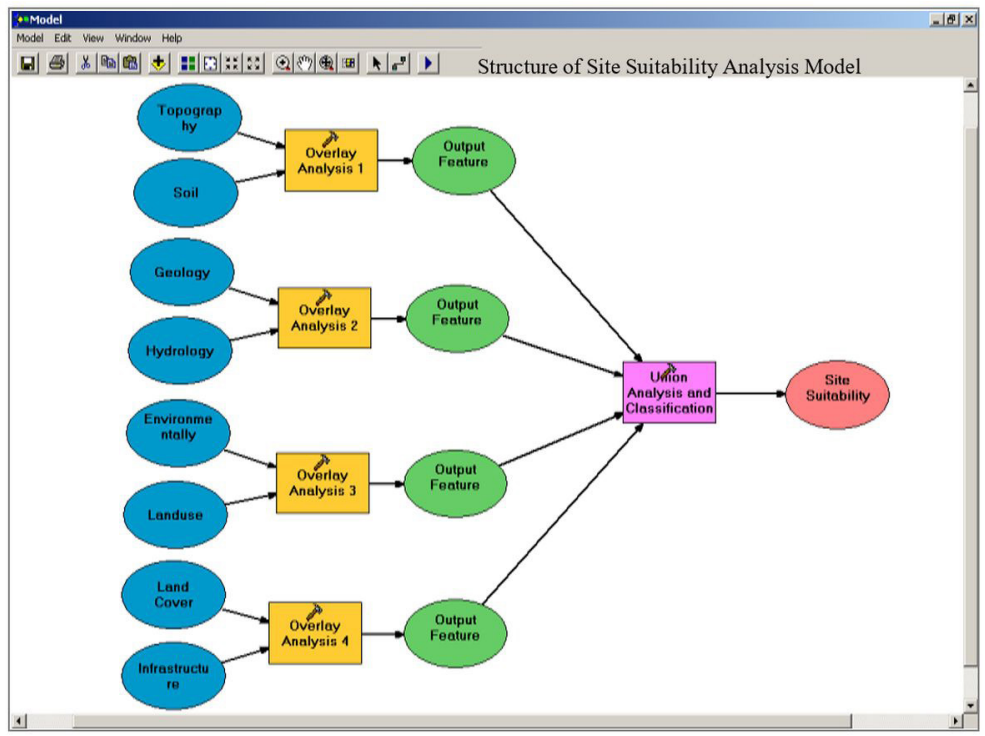

Fig. 2. Structure of Site suitability Analysis Model 
Table:-2 Input Data layer, Data Description, and Suitability Score

\begin{tabular}{|c|c|c|c|c|}
\hline $\begin{array}{l}\text { Input Data } \\
\text { Layer }\end{array}$ & Data Description & Rank & Weight & Score \\
\hline \multirow{3}{*}{ 1. Topography } & Elevation ( 0 to 2.5 meter) & 5 & 1 & 5 \\
\hline & Elevation ( 2.5 to 5.0 meter) & 5 & 8 & 40 \\
\hline & Elevation (More than 5.0 meter) & 5 & 5 & 25 \\
\hline 2.Soil Data & Soil suitability for construction important & 5 & 3 & 15 \\
\hline \multirow{3}{*}{$\begin{array}{l}\text { 3. Geological } \\
\text { Data }\end{array}$} & Soil suitability for open source development & 6 & 6 & 36 \\
\hline & Geological Suitability for Mineral Resource Significance & 7 & 6 & 42 \\
\hline & Geological Suitability for Construction Importance & 4 & 5 & 20 \\
\hline \multirow{7}{*}{ 4. Hydrology } & River (Buffer 0 to 50 meter) & 8 & 7 & 56 \\
\hline & River (Buffer 50 to 250 meter) & 8 & 6 & 48 \\
\hline & Lake (Buffer 0 to 50 meter) & 8 & 9 & 72 \\
\hline & Lake (Buffer 50 to 250 meter & 8 & 8 & 64 \\
\hline & Ocean (Buffer 0 to 500 meter) & 9 & 9 & 81 \\
\hline & Ocean (Buffer 500 to 1000 meter) & 9 & 8 & 72 \\
\hline & Ocean (Buffer 1 to 3 kilometer) & 9 & 7 & 63 \\
\hline \multirow{3}{*}{$\begin{array}{l}\text { 5.Environmen- } \\
\text { tally sensitive } \\
\text { area }\end{array}$} & Area Below 2.5 Meter & -4 & 2 & -8 \\
\hline & White and Yellow Dune Sand & -4 & 3 & -12 \\
\hline & Protective Forest Land & -4 & 7 & -28 \\
\hline \multirow{4}{*}{$\begin{array}{l}\text { 6.Landcover } \\
\text { forest }\end{array}$} & & 6 & 4 & 24 \\
\hline & Forest (Buffer 0 to 1 kilometer) & 6 & 6 & 36 \\
\hline & Forest (Buffer 1 to 3 kilometer) & 6 & 3 & 18 \\
\hline & Open Space & 6 & 2 & 12 \\
\hline \multirow{6}{*}{ 7.Landuse data } & Existing Heritage / Cultural Center & 9 & 9 & 81 \\
\hline & (Buffer 0 to 5 kilometer) & & & \\
\hline & Existing Heritage / Cultural Center & 9 & 8 & 72 \\
\hline & (Buffer 5 to 10 kilometer) & 9 & 7 & 63 \\
\hline & $\begin{array}{l}\text { Existing Heritage / Cultural Center (Buffer } 10 \text { to } 15 \\
\text { kilometer) }\end{array}$ & & & \\
\hline & Built-up Area & 6 & 5 & 30 \\
\hline \multirow{7}{*}{ 8.Infrastructure } & National Highway (Buffer 0 to 1 kilometer) & 7 & 2 & 14 \\
\hline & District Road (Buffer 0 to 1 kilometer) & 7 & 4 & 28 \\
\hline & Minor Road (Buffer 0 to 250 meter) & 7 & 7 & 49 \\
\hline & Coastal Road (Buffer 0 to 500 meter) & 7 & 10 & 70 \\
\hline & Railway Station (Buffer 0 to 4 kilometer) & 7 & 2 & 14 \\
\hline & Airport (Buffer 0 to 10 kilometer) & 7 & 4 & 28 \\
\hline & Airport (Buffer 10 to 20 kilometer) & 7 & 7 & 49 \\
\hline
\end{tabular}




\section{Result and Discussions:}

The travel industry land utilize needs similarly great availability and openness too foundation advancement. Given underneath is the avocation against the travel industry land use reasonableness examination. This arrangement of viewpoints has been utilized to research the fundamental appropriateness of the locale. This stage thinks about all the standard factors that regularly decide the appropriateness of a locale from the travel industry advancement perspective. The scale for gauging and positioning is 1 to 10 , with 1 being relegated to the factor with least significance and the other way around.

\section{Wetland}

Vaishali square is situated in a semi tropical Gangetic plain. The square is limited by the waterway Ganga in the south and is bound by Gandak in west. It is shaped by alluvial soil which is extremely fruitful. The entire investigation zone secured the inland wetland highlights, for example, seepage, streams, waterlogged territory (Zhang et al. 2000). At that point the other ruling classes on the investigation zone are lakes, lakes and normal waterlogged regions (Fig.3).

\section{Environmental sensitive Area}

Explicit territories have been depicted as naturally touchy, this is done to escape negative effects and to keep from aggravating nature perils like flooding and asset decrease. Zones considered under these sorts are; land underneath 2.5 meters, white and yellow sand rise, and defensive woodland land.

\section{Land use/Land cover}

Land use/Land front of the zonegives a solid thought regarding the physiographical and financial development of any district. Remote Sensing innovation has made a significant commitment to the land use mapping (Pande et al. 2018, Turner MG et al. 2001). The Land use/Land Cover classes of the investigation region were mapped for utilizing LANDSAT 8 OLI Satellite information 2016. The satellite information were outwardly translated and appended with field confirmations, the maps were finished. The different Land use/Land Cover classes translated incorporate Built up land, Cropland, Fallow land, Plantation, no man's land and water bodies (Fig.4).

Reachable legacy and social focuses are significant vacation spots. They could be old fashioned social relic site or compositional remains. They clasp an incentive for

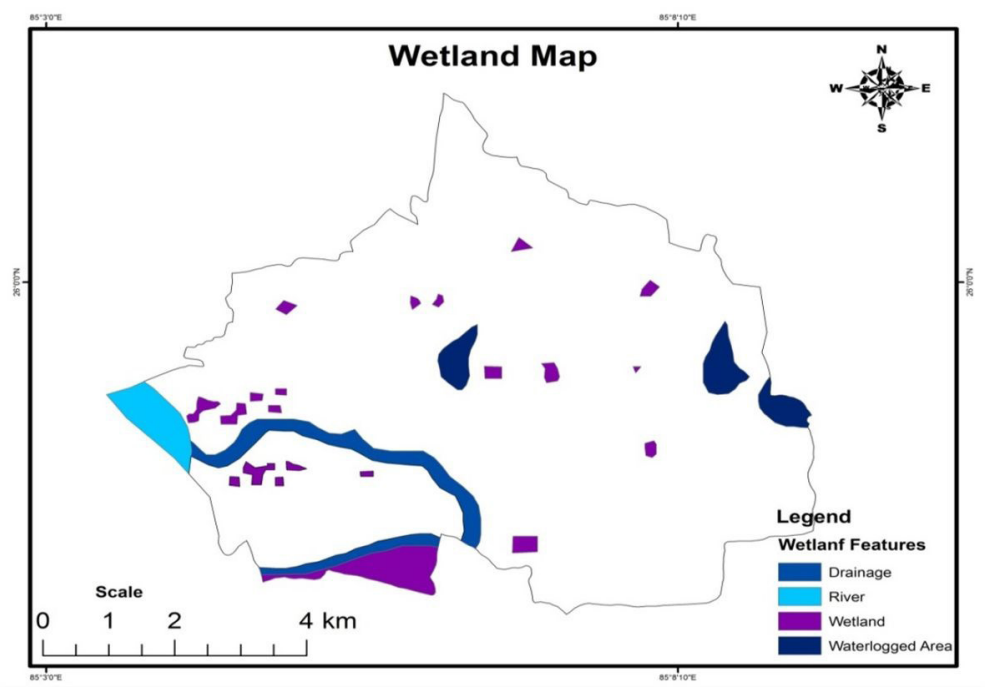

Fig. 3. Wetland Map of Vaishali block 
vacationers as they are an energizing item. Voyagers are plan to see and learn data about new and selective social legacy. Such locales are promising for the travel industry improvement in this way, the most elevated position of 9 has been doled out to these destinations.

\section{a) Forest}

A zone of $1 \mathrm{~km}$ cradle is taken to permit adequate insurance from infringing into woodland zone. A land past this cradle is appropriate for vacationers, as it given a tranquil escape from the contaminated and loud urban regions, much looked for after by the visitor. A positioned of just 6 is given to this land use.

\section{b) Built-up Area / Existing Urban Centers}

Urban center points have just propelled foundations and offices which are basic for setting up the travel industry part. It tends to be additionally improved by making not many recreational zones to draw in vacationers. A position of 6 has been allotted to this land utilize dependent on this condition.

\section{c) Open Spaces}

Open spaces can be settled into a tourist area with the situation that it is vicinity to existing tourist hub.

\section{d) Existing Heritage / Cultural Site}

This site has the imminent to support into significant visitor focus offer with great framework, accordingly it has a high position.

\section{e) Existing Tourism Recreation}

His incorporates beforehand existing pleasantries that go about as a compound for the travel industry improvement and augmentation. It incorporates essential pleasantries like convenience (inns and resorts), visit and travel administrations, recreational spots and extra vacation spots which will fascination more sightseers into the zone.

\section{f) Infrastructure / Facilities}

The travel industry needs a sensible measure of network over land and its adjoining territory. One goes from purpose of inception to the goal in follow of the

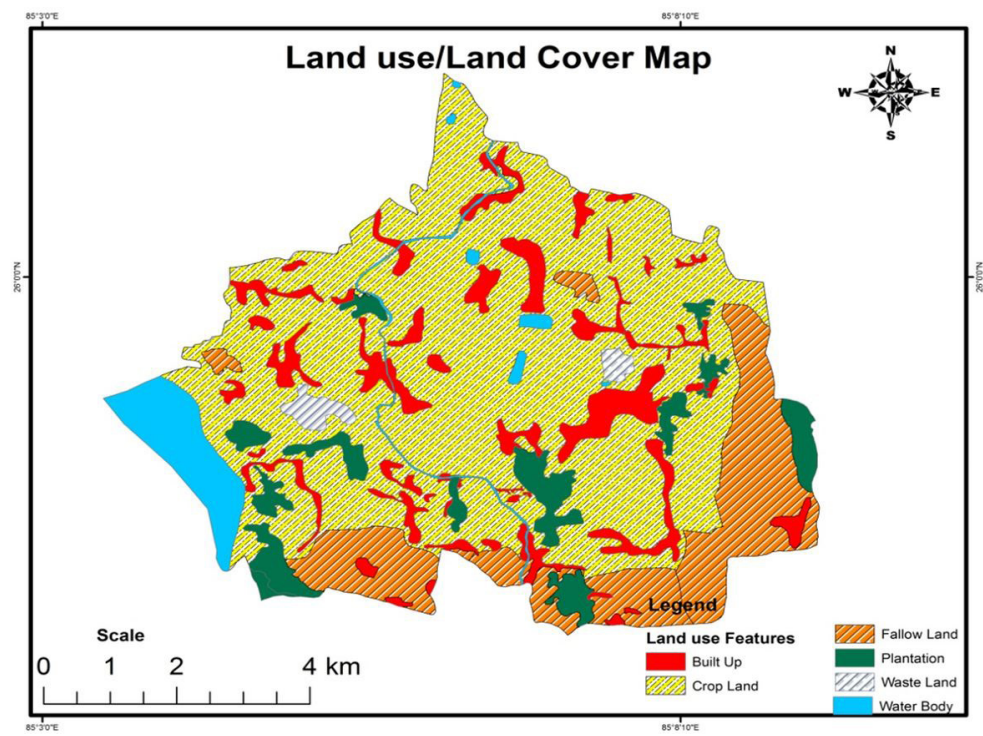

Fig. 4. Land use/Land Cover map of Vaishalai block 
travel industry related exercises. This is just possible by heading out starting with one spot then onto the next through street, rail, and air. Three earnings of transports are utilized for deciding the travel industry reasonableness here.

\section{g) Road}

Street organize interfaces from significant traveler move to the inward pieces of the district. It gives an office to simple and quicker development. In a region where different methods of transport can't be fabricated, the street offers the most helpful income of transport. The street is the fundamental thing thus, it has been appointed with 6 positions.

\section{h) Railway Station}

They are reasonable as well as quicker than street transport. The travel industry imminent territory with railroad network has a superior vision to develop into a bigger the travel industry focus. In light of these railroad stations are likewise distributed with rank 6.

\section{i) Airport}

Air availability is indispensable for the travel industry advancement. Air traffic passes on traveler from inside the nation and furthermore from abroad. Air transport is quickest and most proper method of transport and it encourages travel for sightseers from removed off spots. The travel industry related exercises are not recommended directly by air terminal, since air terminals are likewise significant territory, so a cushion of enough size ought to be permitted. A higher position of 7 has been allocated to air terminal since it is a huge factor in the travel industry advancement.

\section{j) Constraints Selected for Tourism Suitability Analysis are}

Regions that are not appropriate for the travel industry advancement either because of nonattendance of required highlights or the nearness of non-affirming land utilizes are pondered as impediments for the travel industry destinations. These are Ecologically Profound Areas, Existing Forest, Existing Built-up Area, Obtainable Industrial Zone, Lake/Ponds, River, and Ocean.

\section{Multi Hazards Zone}

The fields of vaishali square encased the multi dangers zone chance were recognized all through the territory under Earth shake high harm, and No flood Zone (or) zone secured. (Fig.5)

\section{Outcome of Suitability Map for Tourism Development:}

The last wellness map (Fig.6) has been displayed in a shade of red to green. The green spreads speak to the most extreme appropriate areas for the travel industry improvement while the red spreads connote the least. The most suitable regions are the ones that have an aggregate score near 10 .

\section{Conclusion}

The travel industry is an exceptionally composite action, and accordingly needs apparatuses that guide in genuine basic leadership to grapple with the contending monetary, social, and natural challenges of supportable improvement. Utilizations of GIS in the travel industry and entertainment arranging show that GIS is a strong and successful instrument that can help with the travel industry arranging and basic leadership (Pareta, 2010). The impact of GIS lies not just in the capacity to envision spatial connections, yet in addition past the space to an entire perspective on the world with its many met parts and complex connections. Three huge perceptions that can be produced using the guide are:

1. The most appropriate the travel industry locales perceived by the investigation are inside the significant towns are Rohana, Chhapra, Fetehpur, Basudeo Patti, Chuk Mansur, Vaishali, Chak Ram Das, chhpra. They are contiguous the social legacy focuses with prospect 


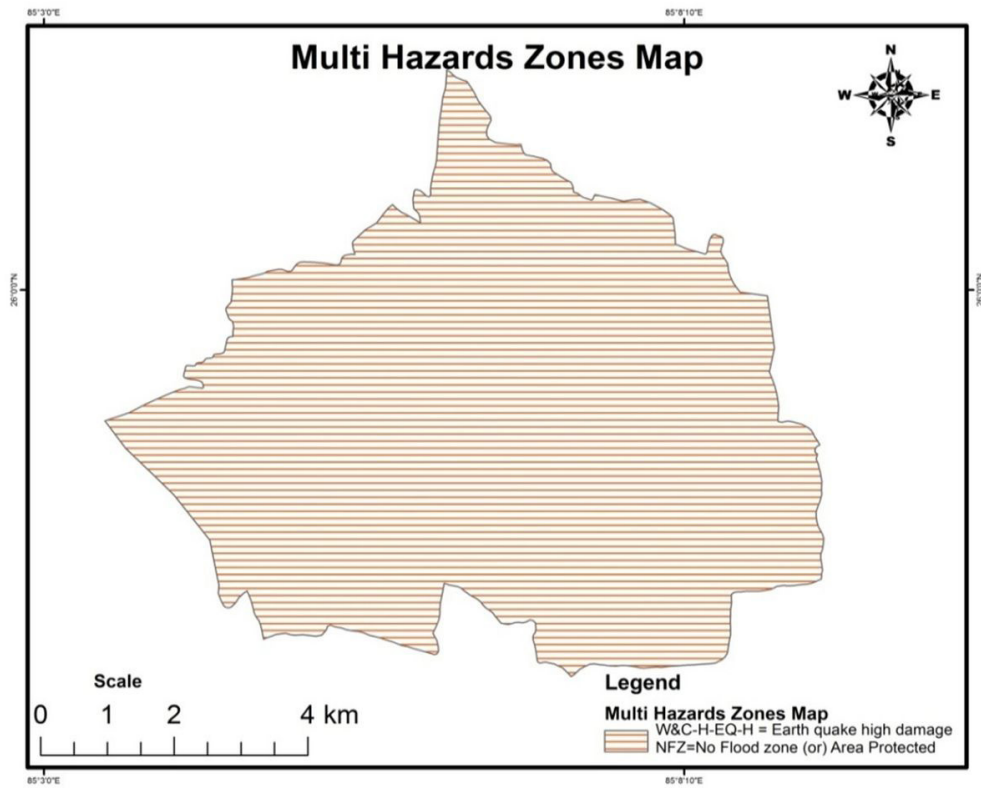

Fig. 3. Wetland Map of Vaishali block

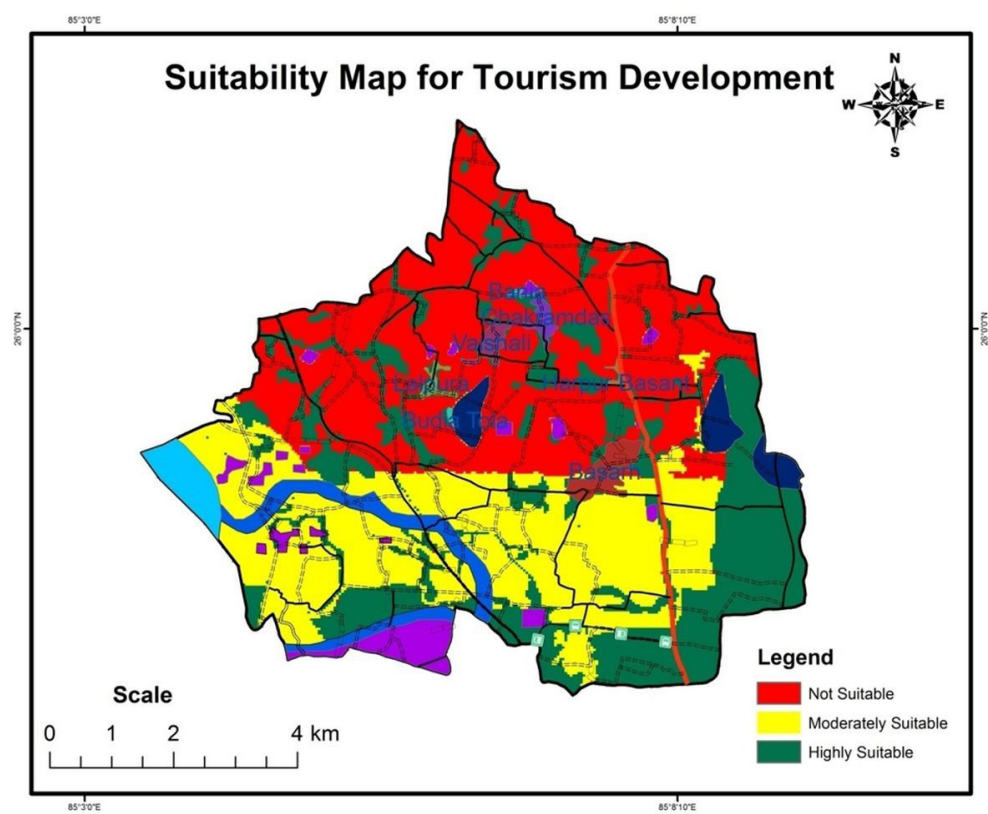

Fig. 3. Wetland Map of Vaishali block

to develop into the travel industry focuses. The rest of the land shows a low reasonableness scale because of absence of principle appreciation for make a solid force factor.
2. Accessibility is a need for the travel industry improvement. Great street arrange availability with region to railroads station or air terminal showed solid traveler potential site, 
this appended with closeness to grand magnificence speaks to high reasonableness.

3. Majorvacation destinations, for example, legacy locales, seaside sea shores and water bodies or lake uncovered solid green shading speaking to high appropriateness. This can be connected to the way that legacy destinations and other high positioning highlights are converted into appropriate the travel industry site. Consequently, the travel industry parts that can be perceived for the travel industry site are (arranged by pecking order dependent on the extent of appropriate regions in that zone):

4. Vaishali, Check Ram Das, Haripur Basand, Basagund towns are perceived as the best reasonable site for the travel industry improvement. It has most extreme green spreads which are deciphered from the current explicit, for example, region to Patna Jaya Prakash Narayana International air terminal, and Hajipur Railway station, are acceptable vehicle framework and open two world legacy site arranged inside the town, and reserves the travel industry augmentation for future.

\section{Summary of research}

According to our present investigation, the most reasonable the travel industry site perceived by the examination is inside significant towns. The urban focus with opportunity to develop into the travel industry focuses. The suffering area shows low reasonableness scale because of absence of significant fascination in make a solid fascination factor. Openness is a need for the travel industry advancement. Great Street organize network with closeness to railroads station or air terminal uncovered solid traveler potential site, this got together with proximity to enchanting excellence speaks to high appropriateness. Significant vacation destinations, for example, legacy locales, gardens and water bodies or lake uncovered high appropriateness. This can be related to the way that legacy destinations and other high reasonable highlights are converted into appropriate the travel industry site.

\section{Future issue}

Because of the brief development of ecotourism, a test for a leader is on the best way to accomplish ecotourism so as to limit the negative effects of reasonable improvement of the travel industry. The benefits of ecotourism being at the focal point of the more extensive arrangement of the travel industry ought to be advanced in the improvement arranging and the executives. GIS performs to be a significant apparatus for arranging, appraisal, and observing of characteristic assets.

\section{Disclosure statement}

There is no special financial support for this research work from the funding agency.

\section{Acknowledgement}

I would like to use this opportunity to sincerely thank my Project coordinator, Dr.T.Phanindra Kumar, Assistant Professor, CGARD, NIRDPR, HYDERABAD, and TELANGANA, INDIA. For allowing me to carry out this research work and encouraged during this period. These works initiated systematic research of a problem and receiving many new results in this area.

\section{References:}

Banerjee, U. K., Kumari, S., Paul, S. K., and Sudhakar, S. (2002), "Remote Sensing and GIS Based Ecotourism Planning - A Case Study for Western Midnapore, West Bengal, India", Map Asia.

Bualhamam, M. R. (2009), "The Study of Urban Growth Impact in Tourism Area using Remote Sensing and GIS Technique for North Part of the UAE", Journal of Geography and Regional Planning Vol. 2(6), pp. 166 - 175

Chettri, P., and Ghimire, G. (1995), "Case Study on the Effects of Tourism on Culture and the Environment", UNESCO Principal Regional 
Office for Asia and the Pacific, Bangkok 10110, Thailand

Dubey, R. (2008), "Applicability of Internet GIS Application in Tourism Industry" Map India

Giles, W. (2003), "GIS Applications in Tourism Planning”, GIS 340 - GIS Seminar, pp. 1 - 11

ICOMOS - International Council on Monuments and Sites (1999), "Evaluations of Cultural Properties", World Heritage Convention Bureau of the World Heritage Committee, WHC-99 / CONF.208 / INF.3

Keeney, R. L., and Raiffa, H. (1993), “Decisions with Multiple Objectives: Preferences and Value Trade-Offs", Cambridge: Cambridge University Press

Laurin, G. V., and Ongaro, L. (2006), "Mapping the Suitability of Potential Conservation Sites: A Case Study in Northern Tunisia”, Journal of Agricultural and Environment for International Development, Vol. 100 (1/2), pp.3 - 28

Ligmann-Zielinska, A., and Jankowski, P. (2008), "A Framework for Sensitivity Analysis in Spatial Multiple Criteria Evaluation", Geographic Information Science, Lecture Notes in Computer Science, Volume 5266/2008, pp. $217-233$

Nagendra, H. (1999), "Biodiversity in the Western Ghats” GIS Development, New Delhi, Vol - 2, pp. $36-41$

Opadeyi, J. And Nizeyimana, E. (2005), "Land Use Planning: Geographical Information System (GIS)", Encyclopedia of Soil Science, Second Edition, CRC Press, No. 203, pp. 978 849
Pareta, K. (2004), "Study of Soil Conservation and Water Resources Management of Bina River Basin (M.P.)", National Geographical Research Conference

Pareta, K. (2010), "Remote Sensing and GIS Application for Potentiality of Ecotourism: A Case Study for Majuli Island, Assam, India", Madhya Bharti Journal, Sagar (M. P.).

Roy, P.S. (1999), "Remote Sensing Application for Forest and Environment: Retrospective and Perspective" Proceeding of ISRS National Symposium, Pub by ISRS and NNRMS, pp. 169 $-185$

Salo, A., and Hamalainen, R. P. (1995), "Multi-criteria Decision Analysis in Group Decision Processes", Helsinki University of Technology, Systems Analysis Laboratory, TKK, Finland

Savigny, D. D., and Wijeyaratne, P. (1994), "GIS for Health and the Environment", Proceedings of an International Workshop held in Colombo, Sri Lanka

Shojaee, D. (2005), "Using GIS and Application for Tourism”, Map Middle East

UN Guideline (1999), “Guidelines on Integrated Planning for Sustainable Tourism Development", Economic and Social Commission for Asia and the Pacific, United Nations, New York

Widjojo, S. (2007), "The Use of Satellite Remote Sensing Imagery to Support Indonesian Tourism, Map Asia

Zopounidis, C., and Doumpos, M. (2002), "Multicriteria Decision Aid Classification Methods", New York: Springer. 